\title{
ДОКТРИНАЛЬНІ ОСОБЛИВОСТІ ГЕНЕЗИСУ СФЕРИ ОБІГУ ЛІКАРСЬКИХ ЗАСОБІВ У ПЕРІОД НЕЗАЛЕЖНОСТІ УКРАЇНИ
}

Постановка проблеми полягає у тому, щоб здійснити доктринальне дослідження генезису розвитку сфери обігу лікарських засобів у період незалежності України до сьогодення. Водночас необхідно обгрунтувати особливості зазначеного історичного періоду сфери обігу лікарських засобів.

Аналіз останніх досліджень і публікацій. У юридичній науці проблематику генезису сфери обігу лікарських засобів розробляли такі вітчизняні та зарубіжні вчені, як: Н.О. Ветютнева, Н.В. Волк, С.Г. Убогов, О.В. Кузьменко, В.К. Колпаков, Г.Г. Пилипенко, А.П. Радченко, М.В. Римар, О.Г. Стрельченко, Л.О. Федорова тощо. Водночас проблемі дослідження генезису сфери обігу лікарських засобів приділено не досить уваги, що, своєю чергою, свідчить про своєчасність і важливість обраної теми наукової статті.

Метою статті є грунтовна характеристика історичного розвитку сфери обігу лікарських засобів.

Виклад основного матеріалу. У перші роки незалежності України було вжито перших заходів щодо виходу сфери обігу лікарських засобів із кризового стану: підприємства хіміко-фармацевтичної промисловості були передані в підпорядкування Міністерства охорони здоров'я України, а також розроблена Державна програма розвитку фармацевтичної промисловості на 1992-1996 роки, спрямована на реконструкцію підприємств і розробку сучасних технологій виготовлення ліків, перш за все життєво необхідних. У цей період створені суб'єкти публічного адміністрування сфери обігу лікарських засобів, такі які Фармакологічний та Фармакопейний комітети, Державна інспекція з контролю якості лікарських засобів, що сприяло прискоренню розробки та впровадження у виробництво лікарських засобів та реєстрації нових вітчизняних та інших лікарських засобів. Завдяки проведеній роботі налагодилося виробництво $з$ імпортної сировини антибіотиків, створено 120 препаратів і профілактичних засобів, із них 10 - принципово нові. МОЗ України були активізовані міжнародні контракти з одержання гуманітарної допомоги, завдяки якій отримано понад 500 тонн вантажів з лікарськими засобами (вакцини проти поліомієліту і кору, наркозні, наркотичні засоби, препарати інсуліну, антибіотики). Відновлювалися стосунки з постачальниками медичної продукції країн СНД, завдяки чому вирішилися проблеми з поставками бактерійних препаратів, сироваток [1].

Новим історичним періодом, який впливає на розвиток сфери обігу лікарських засобів, стає Стратегія інтеграції України до Європейського Союзу. 3 цією метою у 1999 році було створено Національне агентство з контролю за якістю і безпекою продуктів харчування, лікарських засобів і виробів медичного призначення. Йому була підпорядкована Державна інспекція з контролю якості лікарських засобів. Фармакологічний комітет був реорганізований у Державний науково-експертний центр лікарських засобів. Функціонувало близько 12 тис. аптек (53\% - державних, 
$35,6 \%$ - колективної форми власності, $6,4 \%$ - приватних). Створена Фармацевтична асоціація України. Новий період розвитку сфери обігу лікарських засобів, спрямований на інтеграцію до світового співтовариства, ознаменував V Національний з'їзд фармацевтів України. Створена програма «Фармація-2005», в основу якої покладені принципи подальшого реформування сфери згідно з нормами Свропейського Союзу. Основними напрямами розвитку сфери обігу лікарських засобів нового періоду стає створення законодавчої бази і нормативних актів, гармонізація системи стандартизації, нормативно-аналітичного забезпечення, ліцензування та реєстрації у відповідності до вимог Європейського Союзу, забезпечення належної якості препаратів, створення системи інформації про ліки тощо. На перший план виходить проблема доступності ліків для населення. Частка бюджетних коштів у витратах на ліки за попередні роки постійно зменшувалася і у 2000 р. становила $23 \%$. Решту оплачують caмi хворі, велика частина з яких - малозабезпечені верстви населення. Через низьку купівельну спроможність населення багато інофірм стали перед дилемою: або знизити ціни на лікарські засоби, або залишити ринок України. Останнє потягло б за собою зникання асортименту імпортних ліків, необхідних для задоволення потреб охорони здоров'я. Приріст вітчизняного виробництва ліків становив 5,4\%. Загальний обсяг вітчизняних лікарських засобів на ринку збільшився на $11 \%$ і становив до 1300 найменувань. 5 підприемств (3,5\%) дали $21 \%$ ліків; $96,5 \%$ інших $-16 \%$ ліків; $63 \%$ становили імпортні препарати. 2000 рік характеризувався збільшенням обсягу виробництва лікарських засобів на 265 млн грн і у вартісному вигляді досяг 1,1 млрд грн, що є найбільшим показником за останні 10 років. Внутрішній ринок був забезпечений вітчизняними ліками на 40-50\% (за даними різних джерел), їх асортимент досяг приблизно 1500 найменувань. За власні кошти підприємств було освоєно виробництво 90 препаратів. Відповідно до чинного законодавства було утворено Державний департамент з контролю якості, безпеки і виробництва лікарських засобів та виробів медичного призначення. Основними його функціями стали контроль розробки, виробництва, якості лікарських засобів, ліцензування виробництва і реалізації ліків, реєстрація лікарських засобів. На кінець 2000 року в Україні функціонувало 16782 аптек, аптечних пунктів і кіосків. Роздрібний товарообіг становив за рік 2052728,8 тис. грн. Незважаючи на збільшення за останні роки випуску вітчизняних ліків і освоєння виробництва багатьох нових необхідних лікарських засобів, проблема медикаментозного забезпечення населення України не втрачає своєї актуальності. На цей час вітчизняна фармацевтична промисловість виробляє ліки основних фармакотерапевтичних груп у кількості, яка задовольняє близько половини потреби в них. Імпортні препарати за вартістю значно дорожчі, внаслідок чого поглиблюється проблема їх збуту. За розрахунками фахівців мінімальна медикаментозна допомога в цінах на 01 січня 2001 р. становить понад 200 грн на одну особу на рік, тобто близько 20 грн на місяць. Таким чином, на цей час першочерговими завданнями щодо забезпечення населення лікарськими засобами залишаються: підвищення рівня доступності ліків для населення; державне фінансування охорони здоров'я; подальше налагодження виробництва вітчизняних ліків; реструктуризація виробництва згідно зі стандартами GMP. Окремо слід зупинитися на аналізі такого важливого напряму в розвитку сфери обігу лікарських засобів, як науково- 
дослідна діяльність. Необхідно відзначити, що навіть у найскладніші в економічному відношенні і для держави, і для сфери обігу лікарських засобів часи науково-дослідні установи та підприємства-виробники продовжували роботу над створенням нових препаратів та впровадженням їх у виробництво. Україна має великий науковий потенціал [1].

У сфері обігу лікарських засобів відзначалася відсутність достатнього контролю виробництва, випробування та якості препаратів за міжнародними стандартами, в результаті чого постало питання неконкурентоспроможності українських ліків на зовнішньому ринку. Критичне становище щодо забезпечення ліками ускладнювалося недосконалістю законодавчої бази в галузі розробки, виробництва, збуту лікарських засобів, яка б стимулювала виробників і захищала споживачів від неякісної фармацевтичної продукції [1].

Отже, основнили особливостяли періоду салостійності України є такі:

1 ) запроваджена Державна програла розвитку фарлацевтичної пролисловості, яка спрялована на реконструкиію підприєлств і розробку сучасних технологій виготовлення лікарських засобів;

2 ) створені суб'єкти публічного адліністрування сфери обігу лікарських засобів, такі як: Фарлакологічний та Фармакопейний колітети, Державна інспекиія з контролю якості лікарських засобів, Державний науково-експертний иентр лікарських засобів, Національне агентство з контролю за якістю і безпекою продуктів харчування, лікарських засобів і виробів медичного призначення та Державна інспекиія з контролю якості лікарських засобів, за допологою яких прискорено розробки та впровадження у виробниитво лікарських засобів та реєстрація нових вітчизняних та інших лікарських засобів;

3) налагодилося виробництво антибіотиків з ілпортної сировини;

4) налагоджено міжнародні контакти з отрилання гуланітарної допологи;

5 ) збільшився обсяг виробництва лікарських засобів тваринного походження;

6 ) скоротилося виробниитво антибіотиків, анальгетиків, сульфанілалідних і віталінних препаратів;

7 ) був відсутній достатній контроль виробниитва, випробування та якості препаратів за міжнародними стандартали,

8) збільшився експорт ліків;

9) визначена иілеспрялована стратегія інтеграцї Украӥни до Європейського Союзу;

10 ) створена Фарлацевтична асоціація України.

Наступним періодом розвитку сфери обігу лікарських засобів є період сучасної доби (2001 р. - до сьогодення).

Сфера обігу лікарських засобів в Україні стала досить розвинутою та багатогранною завдяки впровадженню реформи у цій сфері. У нашій країні є власне виробництво, яке наближається до світового рівня, розвинута мережа дистриб'юторів та аптечних закладів. Обсяг фармацевтичного ринку неухильно зростає. Основне завдання, яке стоїть перед державою у сфері забезпечення населення лікарськими засобами, є організація стабільної діяльності підприємств сфери обігу лікарських засобів [2]. 
Крім того, серед основних напрямів подальшого розвитку вітчизняної сфери обігу лікарських засобів є необхідність широкого запровадження належних виробничої, дистриб'юторської та аптечної практик, стандартизації застосування і споживання ліків, вирішення питань щодо реклами фармацевтичної продукції тощо [2].

Щодо вітчизняної сфери обігу лікарських засобів, то можна констатувати, що вона стала конкурентоспроможною на європейському ринку, а внутрішній ринок насичений широким асортиментом лікарських засобів. Останнім часом у фармацевтичному секторі відбулося чимало позитивних змін. Насамперед це збільшення обсягів виробництва лікарських засобів, розвиток і упорядкування аптечної мережі, створення механізму впровадження Програми «Доступні ліки» тощо. Але залишилося й багато насущних проблем. Зокрема, потребує подальшого вдосконалення законодавча база у сфері обігу лікарських засобів, $є$ потреба у впровадженні страхової медицини, слід вирішувати питання, пов'язані з недостатнім фінансуванням науки. Фармація України об'єднує нині понад 550 тис. фахівців [2].

Вагомим внеском у зазначений історичний розвиток сфери обігу лікарських засобів є впровадження через ліцензування та акредитацію на підприємствах і в організаціях сфери обігу лікарських засобів за міжнародними стандартами системи забезпечення якості продукції та послуг, відомих у світі під назвами належної виробничої (GMP), клінічної (GCP), лабораторної (GLP), дистриб’юторської (GDP), аптечної (GPP) практик, належної практики з фармаконагляду (GPhVP) та інших належних практик, що значно підвищило якість лікарських засобів в Україні.

Водночас були визначені основні напрями і пріоритети розвитку сфери обігу лікарських засобів, такі як, по-перше, інтеграція України до економічного світового співтовариства; по-друге, глобальні структурні процеси в економіці; по-трете, підвищення рівня забезпечення населення лікарськими засобами; по-четверте, низька соціально-економічна ефективність використання ресурсів охорони здоров'я та фармацевтичного сектору. Суттєвими факторами, що впливають на стандарти функціонування фармацевтичного сектору галузі охорони здоров'я, стан доступності лікарських засобів та охорони здоров'я у цілому, є стан власного фармацевтичного промислового та науково-технічного потенціалу, системи фінансування охорони здоров'я, рівень культури (традицій).

Впровадження реформи сфери обігу лікарських засобів передбачало запровадження в повному обсязі системи реімбурсації лікарських засобів у межах державного гарантованого пакета медичної допомоги. 3 метою реалізації всіх вищевикладених позицій щодо реформування сфери обігу лікарських засобів Міністерство охорони здоров'я України затверджуе та впроваджує у життя цілу низку наказів, спрямованих на забезпечення програми відшкодування вартості ліків.

Так, ще одним важливим елементом історичного розвитку сфери обігу лікарських засобів є також те, що у 2017 році стартувала урядова ініціатива щодо запровадження нового цінового регулювання ліків та програми відшкодування їх вартості під час амбулаторного лікування осіб із серцево-судинними захворюваннями, цукровим діабетом II типу, бронхіальною астмою за переліком 21 міжнародної непатентованої назви лікарських засобів. Відповідно, у цей період було затверджено Порядок відшкодування вартості лікарських засобів, Порядок визна- 
чення розміру відшкодування вартості лікарських засобів, вартість яких підлягає відшкодуванню, форму звіту про відпущені лікарські засоби, а також зміни в урядові постанови, відповідно до яких здійснюється державне регулювання цін на лікарські засоби [3].

Найближчим часом лікарі-ФОП (фізична особа-підприємець), які одержали ліцензію на провадження господарської діяльності з медичної практики, матимуть право виписувати рецепти на лікарські засоби, вартість яких підлягає відшкодуванню в рамках програми «Доступні ліки». У грудні 2018 року перелік безоплатних ліків щодо програми «Доступні ліки» уже збільшився із 5\% до 10\%, а також збільшився перелік захворювань, які підпадають під умови Програми. Перелік безоплатних ліків збільшено щонайменше на 30 препаратів. Відтепер цю можливість матимуть усі фармацевтичні виробники, ціни на медикаменти яких не перевищують 10\% від вартості найдешевшого препарату згідно з міжнародною непатентованою назвою. Таким чином, нині за програмою «Доступні ліки» пацієнти із серцево-судинними захворюваннями, бронхіальною астмою та діабетом 2 типу можуть отримати 261 препарат, з них 59 - безоплатно. Отримати ліки за рецептом від лікаря нині можна в кожній третій аптеці в Україні.

Треба відзначити й те, що уже з 1 квітня 2019 року контрактування аптечних закладів та відшкодовування вартості відпущених лікарських засобів у рамках програми «Доступні ліки» проводитиметься не закладами охорони здоров' я чи муніципалітетами, а безпосередньо одним головним оператором бюджетних коштів, якою є Національна служба здоров’я України. Так, на програму "Доступні ліки» у 2019 році передбачено 1 млрд грн. Відповідне переведення адміністрування програми до Національної служби здоров'я України не вплине на забезпечення пацієнтів ліками на цей час.

Треба відзначити, що з метою реалізації цих програм натепер в Україні працює більше 50 фармацевтичних фабрик, 21 завод і близько 120 фірм. Абсолютна більшість лікарських засобів (75-80\%) випускаються найбільшими підприємствами вітчизняної сфери обігу лікарських засобів тощо.

Висновки. Отже, основними особливостями періоду сучасної доби у сфері обігу лікарських засобів слід визначити такі:

1) завдяки впровадженню реформи сфери обігу лікарських засобів вона стала розвинутою та багатогранною;

2) є власне виробництво лікарських засобів, що наближено до світового рівня;

3) розвинута мережа дистриб'юторів;

4) розвинена мережа аптечних закладів як державної, так і приватної власності;

5) впроваджено Програму «Доступні ліки»;

6) застосовуються міжнародні стандарти щодо ліцензування та акредитації системи забезпечення якості лікарських засобів;

7) запроваджено систему реімбурсації лікарських засобів у межах державного гарантованого пакета медичної допомоги;

8) впроваджена урядова ініціатива щодо запровадження нового цінового регулювання ліків та програми відшкодування їх вартості під час амбулаторного лікування осіб із серцево-судинними захворюваннями, цукровим діабетом II типу, 
бронхіальною астмою згідно із переліком 21 міжнародної непатентованої назви лікарських засобів;

9) відшкодовування вартості відпущених лікарських засобів у рамках програми «Доступні ліки» проводитиметься не закладами охорони здоров'я чи муніципалітетами, а безпосередньо одним головним оператором бюджетних коштів, якою $\epsilon$ Національна служба здоров'я України;

10) запроваджені державні програми щодо фінансування та забезпечення лікарськими засобами хворих із дороговартісним лікуванням із державного бюджету.

\section{Jimepamypa}

1. Черних В. Фармацевтична галузь за роки незалежності України. Вісник фармації. 2002. № 3. URL: http://lib.nuph.edu.ua/fullis/2000-2005/3.pdf.

2. Тлустова Т. Історія створення фармацевтичної промисловості в Україні. Новини медицини та фармації. № 16 (379). 2011 р. С. 2.

3. Міністерством охорони здоров'я України затверджено низку наказів, спрямованих на забезпечення програми відшкодування вартості ліків. URL: https://www.apteka.ua/article/405451?print.

\section{Анотація}

Стрельченко О. Г. Доктринальні особливості генезису сфери обігу лікарських засобів у період незалежності України. - Стаття.

У статті здійснено доктринальне дослідження генезису розвитку сфери обігу лікарських засобів у період незалежності України до сьогодення. Разом із тим виокремлено основні особливості зазначеного історичного періоду сфери обігу лікарських засобів. Так, основними особливостями періоду незалежності України сфери обігу лікарських засобів є такі: впроваджено реформу сфери обігу лікарських засобів, особливим елементом якої є реформування сфери обігу лікарських засобів; розвинуто власне виробництво лікарських засобів, що наближено до світового рівня; розвинена мережа дистриб'юторів, мережа аптечних закладів як державної, так і приватної власності; впроваджено Програму «Доступні ліки»; застосовано міжнародні стандарти щодо ліцензування та акредитації системи забезпечення якості лікарських засобів; запроваджено систему реімбурсації лікарських засобів у межах державного гарантованого пакета медичної допомоги; впроваджена урядова ініціатива щодо запровадження нового цінового регулювання ліків та програми відшкодування їх вартості під час амбулаторного лікування осіб із серцево-судинними захворюваннями, цукровим діабетом II типу, бронхіальною астмою згідно із переліком 21 міжнародної непатентованої назви лікарських засобів.

Ключові слова: обіг, лікарські засоби, період, незалежність України, програма «Доступні ліки», реімбурсація.

\section{Аннотация}

Стрельченко О.Г. Доктринальные особенности генезиса сферы обращения лекарственных средств в период независимости Украины. - Статья.

В статье осуществлено доктринальное исследование генезиса развития сферы оборота лекарственных средств в период независимости Украины до современности. Вместе с тем выделены основные особенности указанного исторического периода сферы обращения лекарственных средств. Так, основными особенностями периода независимости Украины сферы обращения лекарственных средств являются следующие: введена реформа сферы здравоохранения, особым элементом которой является реформирование сферы обращения лекарственных средств; развито собственное производство лекарственных средств, приближенное к мировому уровню; развита сеть дистрибьюторов, сеть аптек как государственной, так и частной собственности; внедрена Программа «Доступные лекарства»; применены международные стандарты по лицензированию и аккредитации системы обеспечения качества лекарственных средств; введена система реимбурсации лекарственных средств в рамках государственного гарантированного пакета медицинской помощи; внедрена правительственная инициатива о введении нового ценового регулирования лекарств и программы возмещения их стоимости при амбулаторном лечении лиц с сердечно-сосудистыми заболеваниями, сахарным диабетом II типа, бронхиальной астмой согласно перечню 21 международного непатентованного названия лекарственных средств.

Ключевые слова: оборот, лекарственные средства, период, независимость Украины, программа «Доступные лекарства», реимбурсация. 


\section{Summary}

Strelchenko O. H. Doctrinal peculiarities of the genesis of the sphere of drug circulation during the period of independence of Ukraine. - Article.

The article deals with the doctrinal study of the genesis of the development of the sphere of drug circulation during the period of Ukraine's independence to the present. At the same time, the main features of this historical period of the sphere of drug circulation are singled out. Thus, the main peculiarities of the period of Ukraine's independence in the sphere of circulation of medicinal products are as follows: the reform of the sphere of circulation of medicinal products has been introduced, a special element of which is the reform of the sphere of drug circulation; developed own production of medicines that is close to the world level; developed network of distributors, chain of pharmacy establishments both state and private property; the "Available Drugs" program is implemented; international standards for licensing and accreditation of the quality assurance system of medicinal products have been applied; a system of reimbursement of medicines in the framework of the state guaranteed package of medical care was introduced; a government initiative on introducing a new price regulation of medicines and programs for their cost recovery during outpatient treatment of people with cardiovascular diseases, Type II diabetes, bronchial asthma according to the list of 21 international non-proprietary names of medicines has been introduced.

Key words: turnover, medicines, period, independence of Ukraine, "Available Medication", program, reimbursation. 